.. Kucuktuvek, Toker, Turkoglu, Gunduz, Altay, Baysal: Improving Weathering Performance...

Mustafa Kucuktuvek', Hilmi Toker², Turkay Turkoglu³, Ahmet Gunduz', Caglar Altay ${ }^{4}$,Ergun Baysal ${ }^{2}$

\title{
Improving Weathering Performance of Wood by Borates Impregnation and Liquid Glass Coating
}

\section{Poboljšanje otpornosti drva na vremenske utjecaje impregnacijom boratima i premazom od tekućeg stakla}

\author{
Original scientific paper • Izvorni znanstveni rad \\ Received-prispjelo: 9. 4. 2019. \\ Accepted-prihvaćeno: 15. 7. 2020. \\ UDK: $630 * 814.11 ; 630 * 829.2$ \\ https://doi.org/10.5552/drvind.2020.1923
}

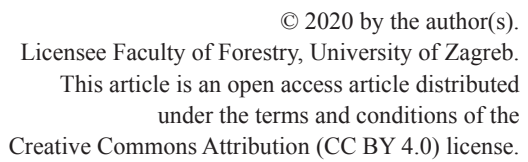

\begin{abstract}
Weathering performance of impregnated and coated wood products is an important issue that influences their appearance as well as their service life after outdoor or indoor exposure. A novel procedure to improve the weathering performance of Scots pine wood (Pinus sylvestris L.) is proposed in this study. Wood samples were impregnated with ammonium tetrafluoroborate (ATFB), ammonium pentaborate (APB) and boric acid (BA), and afterward coated with a layer of liquid glass (LG). Surface hardness, color changes, and surface roughness of wood samples were investigated after $250 \mathrm{~h}$ and $500 \mathrm{~h}$ of exposure to artificial weathering. The results revealed that, except for untreated (control), all other treatment groups caused an increase in surface hardness of Scots pine after weathering. A decrease in the CIE $L^{*}$ value corresponds to the darkening of samples after weathering. Borates-impregnated and LG-coated Scots pine samples possessed the highest color stability. However, all treatment combinations resulted in reddish and yellowish tones after weathering. Exposure to weathering increased surface roughness of wood samples. The surface roughness of the untreated (control) group was higher than that of impregnated and coated samples.
\end{abstract}

Keywords: weathering; boron compounds; liquid glass; wood coating; surface characteristics; building material

SAŽETAK • Otpornost impregniranoga i premazanog drva pri izlaganju vremenskim utjecajima velik je problem koji utječe na izgled $i$ vijek trajanja drva nakon izlaganja u eksterijeru ili interijeru. U ovom je istraživanju predložen novi postupak poboljšanja otpornosti borovine (Pinus sylvestris L.) izložene vremenskim utjecajima. Uzorci drva impregnirani su amonijevim tetrafluoroboratom (ATFB), amonijevim pentaboratom (APB) $i$ bornom kiselinom (BA), nakon čega su premazani tekućim staklom (LG). Ispitivana je tvrdoća površine, promjena boje $i$ hrapavost površine uzoraka drva nakon 250 i 500 sati umjetnog izlaganja vremenskim utjecajima. Rezultati su pokazali da se na svim površinski obrađenim uzorcima borovine povećala tvrdoća njezine površine nakon izlaganja vremenskim utjecajima. Smanjenje vrijednosti CIE L* upućuje na tamnjenje uzoraka nakon izlaganja vremenskim

\footnotetext{
${ }^{1}$ Author is researcher at Antalya Bilim University, Faculty of Fine Arts and Architecture, Department of Interior Architecture and Environmental Design, Antalya, Turkey.

2 Authors are researchers at Mugla Sitki Kocman University, Faculty of Technology, Department of Wood Science and Technology, Mugla, Turkey.

3 Author is researcher at Mugla Sitki Kocman University, Koycegiz Vocational School, Department of Forestry, Mugla, Turkey.

${ }^{4}$ Author is researcher at Adnan Menderes University, Aydin Vocational School, Department of Furniture and Decoration, Central Campus, Aydin, Turkey.
} 
utjecajima. Najbolju stabilnost boje pokazali su uzorci borovine impregnirani boratima i premazani tekućim staklom. Međutim, sve kombinacije površinske obrade rezultirale su povećanjem crvenoga $i$ žutog tona nakon izlaganja uzoraka vremenskim utjecajima. Izlaganjem vremenskim utjecajima povećala se hrapavost površine uzoraka drva. No hrapavost površine kontrolnih uzoraka (površinski neobrađenih) bila je veća nego hrapavost površine impregniranih i premazanih uzoraka.

Ključne riječi: izlaganje vremenskim utjecajima; spojevi bora; tekuće staklo; premaz za drvo; svojstva površine; građevni materijal

\section{INTRODUCTION}

\section{UVOD}

Wood is available throughout the world in both natural and plantation forests, and it is used in a wide range of consumer products, particularly in the interior and exterior building and construction applications (Woodard and Milner, 2016). It was proven that the quality and aesthetic appeal of the value-added woodbased products can be competitive to other non-renewable materials available on the market, determining its economic success (Fell, 2002). Certain coatings, such as paints and varnishes, are commonly used to protect wood against weathering in an exterior environment and to enhance its natural appearance (Cristea et al., 2010). The aesthetic value of wood can quickly be lost if it is not protected from the weather. This can be solved by applying transparent protective finishes or opaque coatings. Clear finishes highlight the natural color and texture of wood, but penetration of solar radiation can degrade the underlying surface and cause the peeling of the finish (Pandey and Pitman, 2002). Special attention should, therefore, be directed to preserve the color of wood-based products because this property adds particular value to the product. Various chemical reactions that cause color and appearance changes are induced by diverse abiotic factors (David et al., 2000). Weathering is one of the major abiotic factors affecting the original color and natural appearance of wood. Ultraviolet (UV) radiation causes the wood color to turn gray, and with constant exposure, the fibers of the wood surface weaken due to depolymerization of lignin and carbohydrates in the cell wall. When wood is exposed to sunlight, lignin absorbs UV light and is responsible for color changes in these wood components. Fungal growth, warping, checking, and splitting can also occur on the wooden surface after a specific exposure time (Mohebby and Saei, 2015; Ghosh et al., 2009).

The color change of heat-treated wood species (ash, iroko, Scots pine, and spruce) was investigated during natural weathering. It was found that there was apparent color fading of wood surfaces after exposure (Tomak et al., 2014). The weathering process was primarily linked to the sunlight irradiation and its rate was increased by higher air temperature, moisture, and other pollutants in the outdoor environment (Pandey, 2005). Accordingly, ultraviolet (UV) radiation and moisture were identified as the main causes of deterioration and discoloration of wood surfaces in weather conditions (Huang et al., 2012; Berdahl, 2008). Coating of the wood surface may be considered as a solution to reduce the effects of weather conditions on material deterioration and to preserve the aesthetic properties of the material exposed outdoor in different cardinal directions or varying design details (Herrera et al., 2018). Weathering is defined as the slow decomposition of materials exposed to weather factors (Sandak et al., 2015). Weathering effects can be observed depending on the type of wood or process. Although natural weathering is usually a relatively slow process, artificial weathering plays an important role in evaluating coatings by obtaining performance assessments in much shorter times than natural weathering. While artificial weathering methods do not fully represent actual material changes in certain weather conditions, they are generally considered to be a very useful tool for predicting surface resistance and future product performance (Evans et al., 2005; Jankowska and Kozakiewicz, 2014). Accordingly, ultraviolet (UV) radiation and moisture were identified as the main causes of deterioration and discoloration of wood surfaces in weather conditions (Huang et al., 2012; Berdahl, 2008).

In the wood preservation industry, traditional wood preservatives are used to prevent the degradation of wood by biological organisms. However, many common wood preservatives, such as copper chromium arsenate (CCA), are prohibited due to their harmful environmental effects. In recent years, research has produced a new generation of improved wood preservatives to extend the service life of wood material. Natural extracts are among the most important environmentally friendly wood preservatives, and many studies have reported that natural plant extracts can protect wood against biological organisms (Salem et al., 2016).

Boron compounds have been recognized and accepted as wood preservatives against insects and fungi (Thevenon et al., 1997). Boron compounds are relatively cost-effective. Despite their many advantages, boron compounds cannot provide complete protection for outdoor applications due to their low leaching performance (Kartal and Green, 2002; Kartal and Imamura, 2004).

Liquid glass (LG) is a two-component product used for waterproofing of surfaces requiring high chemical and physical resistance. It possesses excellent water resistance and can be produced as a transparent or color product that is resistant to atmospheric conditions. LG is not affected by UV light radiation and outdoor weather conditions (http://www.isonem. com, 2019).

The durability of the material and its performance against weathering play an important role in material selection in the building and furniture industry. Cus- 
tomers expect environmentally friendly, sustainable, aesthetic, and durable wood-based materials for interior and exterior spaces. Hardness, color, and roughness of the wood surface are, therefore, important parameters in the construction and building sector. Architects demand high-performance wooden materials for their design. Boron compounds are one of the most environmentally friendly, nontoxic for human health, and advanced impregnation materials. This study aimed to improve the weathering performance of borates-impregnated and LG coated Scots pine wood according to market expectations.

\section{MATERIALS AND METHODS}

2. MATERIJALI I METODE

\subsection{Materials}

2.1. Materijali

\subsubsection{Experimental samples}

2.1.1. Eksperimentalni uzorci

Straight-grained and defect-free sapwood samples of Scots pine (Pinus sylvestris L.) wood were prepared according to ASTM D 358-98 standard (1998). The approximate initial moisture content of the samples was $12 \%$ and the dimensions of samples used in the experiment were $6 \mathrm{~mm}$ (radial) $\times 75 \mathrm{~mm}$ (tangential) $\times 150 \mathrm{~mm}$ (longitudinal). Each sample was sanded with P180 grit sandpaper to obtain a smooth surface. Then wood samples were oven dried at $50 \pm 5^{\circ} \mathrm{C}$ until constant weight. Ten replicate samples $(n=10)$ were prepared for each surface finishing variation.

\subsubsection{Impregnation procedure}

2.1.2. Postupak impregnacije

The test samples were impregnated with $4 \%$ aqueous solution of ammonium tetrafluoroborate (ATFB), ammonium pentaborate (APB), and boric acid (BA) according to ASTM D1413-07e1 (2007). A vacuum desiccator was used for the impregnation process. It was connected to a vacuum pump through a vacuum trap. The vacuum was carried out at $760 \mathrm{~mm} \mathrm{Hg}$ for 30 minutes before supplying the solution into the chamber, followed by a further 30 minutes at $760 \mathrm{~mm} \mathrm{Hg}$ diffusion time under vacuum.

Retention $R$ values of chemicals were calculated using Eq. 1:

$$
\text { Retention }=\frac{G \cdot C}{V} \cdot 10^{3}\left(\mathrm{~kg} / \mathrm{m}^{3}\right)
$$

Where: $G=\left(T_{2}-T_{1}\right)-$ mass of impregnating solution absorbed by wood sample (g)

$T_{1}$ - mass of wood sample before impregnation $(\mathrm{g})$

$T_{2}$ - mass of wood sample after impregnation $(\mathrm{g})$

$C$ - concentration of impregnating solution (\%)

$V$ - volume of wood specimen $\left(\mathrm{cm}^{3}\right)$

\subsubsection{Liquid glass}

\subsubsection{Tekuće staklo}

Liquid glass (LG), used for experimental samples coating, was provided by Isonem Liquid Glass Paint and Insulation Technologies in Izmir, Turkey, a construction industry trade joint-stock company.
LG was applied to the surfaces of test samples according to the manufacturers' instructions. The viscosity of the LG was $18 \mathrm{~s}$ via using DIN 4 cup at $20 \pm$ $2{ }^{\circ} \mathrm{C}$ as recommended by the coating manufacturer. A and $\mathrm{B}$ component ratios were determined $7 / 1$, respectively, according to the manufacturer's suggestions.

The LG was applied to all surfaces and sides of the wood samples with a spray gun according to ASTM D3023-98 standard (2013). The filler was not used to avoid potential interference with the surface characteristics of wood. Instead of using the filler, LG was applied twice. Spreading rate and time were $200 \mathrm{~g} / \mathrm{m}^{2}$ and 48 hours, respectively. After the application of the top coating of LG to the surfaces, wood specimens were conditioned at $20^{\circ} \mathrm{C}$ and $65 \%$ relative humidity for 3 weeks.

\subsection{Methods \\ 2.2. Metode}

Non-toxicity, fire resistance, aesthetics, and durability are among the desired material characteristics. Therefore, borates, which have high fire resistance and are not harmful to human health, were selected to impregnate Scots pine wood in this research.

In this study, impregnated and coated Scots pine wood was exposed to artificial weathering. Selected surface properties, such as hardness, color and roughness were investigated along the experiment to understand the changes of some physical and aesthetics characteristics. The arithmetic mean and standard deviation were calculated as a measure of repeatability and fit of experimental results.

\subsubsection{Artificial weathering}

2.2.1. Umjetno izlaganje vremenskim utjecajima

The artificial weathering test was performed according to ASTM G154-06 standard (2016) in a QUV weathering tester with eight UVA 340 lamps. Wood samples were exposed to artificial weathering for $250 \mathrm{~h}$ and $500 \mathrm{~h}$, corresponding to light irradiation of $8 \mathrm{~h}$, followed by a de-ionized water condensation for $4 \mathrm{~h}$ cycles, respectively. The chamber temperatures during the light irradiation and condensation periods were 60 ${ }^{\circ} \mathrm{C}$ and $50{ }^{\circ} \mathrm{C}$, respectively. The average irradiance was $0.89 \mathrm{Wm}^{2} / \mathrm{nm}^{1}$ at $340 \mathrm{~nm}$ of light wavelength.

\subsubsection{Surface hardness test}

2.2.2. Mjerenje tvrdoće površine

The surface hardness of Scots pine wood samples was measured with the König hardness according to ASTM D 4366-14 (2014). The specimen was positioned on a panel table and a pendulum was placed on the panel surface. The pendulum was deflected for $6^{\circ}$ and released, triggering the start of the timer. The time needed to decrease the pendulum amplitude from $6^{\circ}$ to $3^{\circ}$ corresponded to the König hardness estimate.

\subsubsection{Color test}

\subsubsection{Mjerenje boje}

The color test parameters $L^{*}, a^{*}$, and $b^{*}$ were determined according to the CIE $L * a * b *$ method. The $L^{*}$ color coordinate represents the lightness, whereas $a^{*}$ and $b^{*}$ are related to the chromaticity. The $L^{*}$ value can 
vary from 100 (white) to 0 (black). The value of $a^{*}$ represents red (positive) or green (negative) tones. Correspondingly, the positive $b^{*}$ parameter corresponds to yellow, whereas negative $b^{*}$ represents blue. (Zhang, 2003).

The color of test samples was measured by the X-Rite colorimeter (SP Series Spectrophotometer, Xride Pantone, USA) before and after both artificial weathering periods. The total color change $\left(\Delta \mathrm{E}^{*}\right)$ was determined for each wood material according to ASTM D1536-58T (1964). The observer angle was $10^{\circ}$ and the standard illuminant was D65.

The color changes were calculated according to Eqs. 2 to 5.

$$
\begin{gathered}
\Delta a^{*}=a_{f}^{*}-a_{i}^{*} \\
\Delta b^{*}=b_{f}^{*}-b_{i}^{*} \\
\Delta L^{*}=L_{f}^{*}-L_{i}^{*} \\
\Delta E^{*}=\sqrt{\left(\Delta L^{*}\right)^{2}+\left(\Delta a^{*}\right)^{2}+\left(\Delta b^{*}\right)^{2}}
\end{gathered}
$$

Where $\Delta a^{*}, \Delta b^{*}$ and $\Delta L^{*}$ represent the differences between the color coordinates before and after artificial weathering.

\subsubsection{Surface roughness test}

\subsubsection{Mjerenje hrapavosti površine}

The surface roughness of the wood samples was measured by the Mitutoyo Surftest SJ-301 (Mitutoyo Corporation. Tokyo. Japan) according to DIN 4768 (1990). The surface roughness profile was scrutinized by means of the stylus with a diamond tip of $5 \mu \mathrm{m}$ radius and $90^{\circ}$ conical angle. The feed speed of the stylus was $0.5 \mathrm{~mm} / \mathrm{s}^{1}$ along $8 \mathrm{~mm}$ sampling length (Zhong et al., 2013). Three parameters, which are typically used for wood roughness quantification, were computed, including mean arithmetic deviation of the profile $(R a)$, mean peak-to-valley height $(R z)$, and root mean square $(R q)$ (Hiziroglu and Graham, 1998; Zhong et al., 2013). The cut-off of the filter was $2.5 \mathrm{~mm}$.

\section{RESULTS AND DISCUSSION}

\section{REZULTATI I RASPRAVA}

\subsection{Retentions of wood samples}

3.1. Retencija uzoraka drva

The retention results of Scots pine wood impregnated with $4 \%$ impregnation solution of chemicals are shown in Table 1. The highest amount of retention was noticed in samples impregnated with BA, while the lowest amount of retention was obtained in the experimental samples impregnated with APB.

\subsection{Surface hardness}

3.2. Hrapavost površine

Surface hardness values of the borates-impregnated and LG-coated Scots pine wood samples before and after the artificial weathering process are summarized in Table 2.

Borates impregnation and LG coating increased the hardness of Scots pine surface before artificial weathering. The hardness of untreated (control) wood was 29.3 and increased to 49.4 and 64.4, respectively, after impregnation and LG coating. This might be due to the hardness properties and composition of borates and LG. It was also observed that the surface hardness of the untreated Scots pine decreased after artificial weathering.

The results of the surface hardness of wood materials after weathering obtained in this experiment are in line with other scientific studies. Softening of the untreated Scots pine wood surface and decrease of its hardness after weathering was reported by several re-

Table 1 Retentions of wood samples

Tablica 1. Retencija uzoraka drva

\begin{tabular}{|c|c|c|c|c|c|c|c|c|}
\hline \multirow[t]{2}{*}{$\begin{array}{l}\text { Impregnation and } \\
\text { coating types } \\
\text { Vrste impregnacije } i \\
\text { premaza }\end{array}$} & \multicolumn{2}{|c|}{$\begin{array}{l}\text { Before artificial } \\
\text { weathering } \\
\text { Prije umjetnog } \\
\text { izlaganja } \\
\text { vremenskim } \\
\text { utjecajima }\end{array}$} & \multicolumn{2}{|c|}{$\begin{array}{c}\text { After } 250 \mathrm{~h} \text { artificial } \\
\text { weathering } \\
\text { Nakon } 250 \mathrm{~h} \\
\text { umjetnog izlaganja } \\
\text { vremenskim } \\
\text { utjecajima }\end{array}$} & \multicolumn{2}{|c|}{$\begin{array}{l}\text { After } \mathbf{5 0 0} \mathbf{h} \text { artificial } \\
\text { weathering } \\
\text { Nakon } 500 \mathrm{~h} \\
\text { umjetnog izlaganja } \\
\text { vremenskim } \\
\text { utjecajima }\end{array}$} & \multirow[t]{2}{*}{$\begin{array}{c}\text { Change } \\
\text { after 250 } \\
\text { hours } \\
\text { Promjena } \\
\text { nakon } 250 \mathrm{~h} \\
\% \\
\end{array}$} & \multirow[t]{2}{*}{ 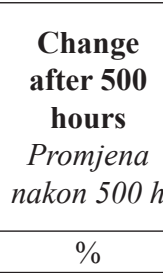 } \\
\hline & Mean & $S D$ & Mean & $S D$ & Mean & $S D$ & & \\
\hline Control / kontrolni uzorci & 29.33 & 2.80 & 23.83 & 3.43 & 23.67 & 1.86 & -18.75 & -19.32 \\
\hline $\begin{array}{l}\text { ATFB + Liquid glass } \\
\text { ATFB + tekuće staklo }\end{array}$ & 49.60 & 3.36 & 62.40 & 4.34 & 70.20 & 5.72 & 25.80 & 41.53 \\
\hline $\begin{array}{l}\text { APB + Liquid glass } \\
A P B+\text { tekuće staklo }\end{array}$ & 49.40 & 4.16 & 71.80 & 2.49 & 73.00 & 6.67 & 45.34 & 47.77 \\
\hline $\begin{array}{l}\text { BA + Liquid glass } \\
B A+\text { tekuće staklo }\end{array}$ & 64.40 & 1.95 & 55.80 & 4.49 & 56.00 & 4.64 & 13.35 & 13.04 \\
\hline $\begin{array}{l}\text { Liquid glass } \\
\text { tekuće staklo }\end{array}$ & 53.60 & 4.04 & 78.80 & 6.98 & 65.80 & 4.82 & 47.01 & 22.76 \\
\hline
\end{tabular}

\begin{tabular}{|c|c|c|c|}
\hline $\begin{array}{c}\text { Impregnation } \\
\text { solution } \\
\text { Otopina } z a \\
\text { impregnaciju }\end{array}$ & $\begin{array}{c}\text { Concentration } \\
\text { Koncentacija } \\
\%\end{array}$ & $\begin{array}{c}\text { Retention } \\
\text { Retencija } \\
\mathrm{kg} / \mathrm{m}^{3}\end{array}$ & $\begin{array}{c}\text { Standard } \\
\text { deviation } \\
\text { Standardna } \\
\text { devijacija }\end{array}$ \\
\hline ATFB & 4 & 24.82 & 5.6 \\
\hline APB & 4 & 22.94 & 3.9 \\
\hline BA & 4 & 25.77 & 4.3 \\
\hline
\end{tabular}

Table 2 Surface hardness values of samples before and after artificial weathering

Tablica 2. Vrijednosti hrapavosti površine uzoraka prije i nakon umjetnog izlaganja vremenskim utjecajima

$S D$ - Standard deviation / standardna devijacija 
searchers (Ustun et al., 2016; Turkoglu et al., 2015; Baysal, 2012; Yalinkilic et al., 1999). However, the opposite trend was observed for impregnated and LG coated samples investigated in this test, where hardening of wood surface occurred after $250 \mathrm{~h}$ and $500 \mathrm{~h}$ artificial weathering. The highest surface hardness increase was noticed for LG-coated Scots pine after 250 $\mathrm{h}$ of exposure. However, it decreased after continuous weathering. Surface hardness increased after $500 \mathrm{~h}$ artificial weathering for APB and ATFB-impregnated and LG-coated samples. After $500 \mathrm{~h}$ artificial weathering, the highest hardness was noticed for APB-impregnated and LG-coated Scots pine.

Cakicier et al. (2011) found that the surface hardness of wood samples coated with water-based varnish increased after artificial weathering for $432 \mathrm{~h}$. They attributed this increase to some modifications in molecular cohesion induced by UV rays, which has a great effect on varnish layer hardness. Polymerization reactions occur and crosslinks are formed between the varnish molecules as the large molecules are cured, which increases the hardness of the wood coating system. De Meijer (2002) claimed that an increase in the temperature of thermal weathering could increase molecular cohesion among the resin molecules of the varnish layers. Baysal (2008) found that synthetic varnish (SV) and polyurethane varnish (PV) coating together with copper chrome boron (CCB) impregnation hardened wood surfaces after 3 months of outdoor natural weathering. In another study, Baysal (2011) reported that the increase in wood surface hardness of CCB-impregnated and synthetic varnish-coated samples was higher than of those treated with CCB-impregnated and coated with polyurethane varnish. The analysis was performed after artificial weathering exposure for $500 \mathrm{~h}$. Baysal et al. (2014) investigated surface hardness of Scots pine pre-impregnated with copper-based chemicals before varnish coating after $500 \mathrm{~h}$ artificial weathering. They found that all impregnated and coated wood increased its surface hardness after $500 \mathrm{~h}$ artificial weathering. The experimental results reported here are therefore in good agreement with these researchers' findings.

\subsection{Color change \\ 3.3. Promjena boje}

Table 3 shows $L^{*}, a^{*}$, and $b^{*}$ values of untreated (control) and impregnated and LG-coated Scots pine samples before and after artificial weathering. The table presents changes for each color coordinate $\left(\Delta L^{*}\right.$, $\Delta a^{*}$, and $\left.\Delta b^{*}\right)$ as well as the total color change $\left(\Delta E^{*}\right)$ for wood samples after 250 and $500 \mathrm{~h}$ artificial weathering. Before artificial weathering, all treatment combinations showed a decrease of $L^{*}$ values (62.97 to 68.63) when compared to the untreated (control) samples (75.69). Before artificial weathering, lightness $L^{*}$ of LG-coated (not-impregnated) Scots pine was higher than that of borates-impregnated and LG-coated samples. It indicates a more profound darkening of wood after the borates treatment. These results are in good agreement with those of Baysal (2012), Ustun et al.
(2016), and Simsek and Baysal (2012), who investigated the effects of some impregnation materials on color changes of wood surface.

Results of the test revealed that, while $a^{*}$ value of control was higher than that of other treatment groups, $b^{*}$ values of borates-impregnated and LG-coated Scots pine were higher than those of the control group. CIE $a^{*}$ and $b^{*}$ values of un-treated Scots pine (control) were 5.9 and 54.6 before artificial weathering. While $a^{*}$ values changed from 6.6 to $9.4, b^{*}$ values changed from 48.0 to 53.0 for borates-impregnated and LGcoated Scots pine.

A negative lightness change $\left(\Delta L^{*}\right)$ occurred after 250 and $500 \mathrm{~h}$ of artificial weathering for un-treated (control) and all borates-impregnated and LG-coated Scots pine samples. $\Delta L *$ is the most sensitive parameter describing color changes of wood surface. Therefore, the wood surface became rougher and darker after weathering. The darkening of Scots pine due to weathering is related to the photodegradation and leaching of lignin and other non-cellulosic polysaccharides (Sonmez et al., 2011; Petric et al., 2004; Hon and Chang, 1985). While positive values of $\Delta a^{*}$ indicate a tendency of the Scots pine wood surface to become reddish, positive values of $\Delta b^{*}$ indicate that the Scots pine wood surface tends to turn yellow. After 250 and $500 \mathrm{~h}$ of weathering, positive $\Delta a^{*}$ and $\Delta b^{*}$ indicate that the investigated wood surfaces maintained a reddish and yellowish tone after weathering.

Total color change $\Delta E^{*}$ of untreated (control) was between 20.6 and 22.7 after 250 and $500 \mathrm{~h}$ of weathering, respectively. The reduction of $\Delta E^{*}$ in borates-impregnated and LG-coated woods suggests a positive contribution of finishing and improved color stability. The best stability after $500 \mathrm{~h}$ of artificial weathering was noticed in APB-impregnated and LGcoated Scots pine. Borates impregnation before LGcoating stabilized color changes due to weathering. It might be due to the photo stabilization of wood via borate treatments, which could be explained by retardation of the carbonyl group formation and reduced delignification due to weathering (Temiz et al., 2005).

\subsection{Surface roughness}

\subsection{Hrapavost površine}

The overall surface quality of wood is defined by several properties, with well-recognized importance of surface roughness (Yildiz et al., 2011). However, wood is heterogeneous, anisotropic and fragile material. The roughness of the surface of wood materials depends on many factors such as the anatomical characteristics of wood (vessels, light of cells, width of annual rings, hardness, etc.), conditions of machining process (speed of feed, cutting speed, etc.) and cutting properties (Karagoz et al., 2011). In addition, rough-surfaced wood materials require much more sanding than smooth-surfaced materials resulting in a decrease in the thickness of the material and consequently an increase in sanding losses (Dundar et al., 2008). The evolution of wood surface roughness parameters $(R a, R z$, and $R q)$ before and after artificial weathering is summarized in Table 4 . Before 
Kucuktuvek, Toker, Turkoglu, Gunduz, Altay, Baysal: Improving Weathering Performance... ..

Table 3 Color changes of samples before and after artificial weathering

Tablica 3. Promjene boje uzorka prije i nakon umjetnog izlaganja vremenskim utjecajima

\begin{tabular}{|c|c|c|c|c|c|c|c|c|c|}
\hline \multirow[t]{2}{*}{$\begin{array}{l}\text { Impregnation and } \\
\text { coating types } \\
\text { Vrste impregnacije } i \\
\text { premza }\end{array}$} & \multicolumn{3}{|c|}{$\begin{array}{c}\text { Before artificial weathering } \\
\text { Prije umjetnog izlaganja } \\
\text { vremenskim utjecajima }\end{array}$} & \multicolumn{3}{|c|}{$\begin{array}{l}\text { After } 250 \text { h artificial } \\
\text { weathering } \\
\text { Nakon } 250 \text { h umjetnog } \\
\text { izlaganja vremenskim } \\
\text { utjecajima }\end{array}$} & \multicolumn{3}{|c|}{$\begin{array}{l}\text { After } 500 \text { h artificial } \\
\text { weathering } \\
\text { Nakon } 500 \text { h umjetnog } \\
\text { izlaganja vremenskim } \\
\text { utjecajima }\end{array}$} \\
\hline & $L_{\mathrm{i}}^{*}$ & $a_{\mathrm{i}}^{*}$ & $b_{i}^{*}$ & $L_{\mathrm{f}}^{*}$ & $a_{\mathrm{f}}^{*}$ & $b_{\mathrm{f}}^{*}$ & $L_{\mathrm{f}}{ }^{*}$ & $a_{\mathrm{f}}^{*}$ & $b_{\mathrm{f}}^{*}$ \\
\hline Control / kontrolni uzorci & 75.69 & 5.87 & 54.58 & 59.02 & 12.29 & 47.37 & 54.58 & 12.12 & 42.52 \\
\hline $\begin{array}{l}\text { ATFB + Liquid glass } \\
\text { ATFB + tekuće staklo }\end{array}$ & 67.58 & 9.40 & 47.96 & 51.64 & 12.78 & 47.70 & 47.96 & 13.95 & 48.43 \\
\hline $\begin{array}{l}\mathrm{APB}+\text { Liquid glass } \\
A P B+\text { tekuće staklo }\end{array}$ & 62.97 & 6.55 & 49.34 & 53.23 & 10.43 & 48.90 & 49.34 & 11.99 & 49.39 \\
\hline $\begin{array}{l}\text { BA + Liquid glass } \\
B A+\text { tekuće staklo }\end{array}$ & 65.08 & 6.72 & 50.57 & 52.75 & 10.10 & 45.78 & 50.57 & 11.82 & 48.08 \\
\hline \multirow[t]{3}{*}{$\begin{array}{l}\text { Liquid glass } \\
\text { tekuće staklo }\end{array}$} & 68.63 & 7.35 & 53.03 & 55.57 & 10.97 & 49.10 & 53.03 & 12.61 & 52.17 \\
\hline & \multicolumn{5}{|c|}{$\begin{array}{l}\text { Total color change after } 250 \text { hours } \\
\text { Ukupna promjena boje nakon } 250 \mathrm{~h}\end{array}$} & \multicolumn{4}{|c|}{$\begin{array}{l}\text { Total color change after } \mathbf{5 0 0} \text { hours } \\
\text { Ukupna promjena boje nakon } 500 \mathrm{~h}\end{array}$} \\
\hline & $\Delta L^{*}$ & $\Delta a^{*}$ & $\Delta b^{*}$ & $\Delta E^{\prime}$ & & $L^{*}$ & $\Delta a^{*}$ & $\Delta b^{*}$ & $\Delta E^{*}$ \\
\hline Control / kontrolni uzorci & -16.67 & 6.42 & 10.19 & 20.5 & & .11 & 6.25 & 5.34 & 22.65 \\
\hline $\begin{array}{l}\text { ATFB + Liquid glass } \\
\text { ATFB + tekuće staklo }\end{array}$ & -15.94 & 3.38 & 8.32 & 18.2 & & .62 & 4.55 & 9.05 & 22.08 \\
\hline $\begin{array}{l}\mathrm{APB}+\text { Liquid glass } \\
A P B+\text { tekuće staklo }\end{array}$ & -9.74 & 3.88 & 9.47 & 14.1 & & 63 & 5.44 & 9.96 & 17.73 \\
\hline $\begin{array}{l}\mathrm{BA}+\text { Liquid glass } \\
B A+\text { tekuće staklo }\end{array}$ & -12.33 & 3.38 & 9.62 & 15.9 & & .51 & 5.1 & 11.92 & 19.45 \\
\hline $\begin{array}{l}\text { Liquid glass } \\
\text { tekuće staklo }\end{array}$ & -13.06 & 3.62 & 12.6 & 18.5 & & 5.6 & 5.26 & 15.67 & 22.72 \\
\hline
\end{tabular}

Table 4 Surface roughness of samples before and after artificial weathering

Tablica 4. Hrapavost površine uzoraka prije i nakon umjetnog izlaganja klimatskim utjecajima

\begin{tabular}{|c|c|c|c|c|c|c|c|c|c|}
\hline \multirow[t]{2}{*}{$\begin{array}{l}\text { Impregnation and } \\
\text { coating types } \\
\text { Vrste impregnacije } i \\
\text { premaza }\end{array}$} & \multicolumn{3}{|c|}{$\begin{array}{c}\text { Before artificial weathering } \\
\text { Prije umjetnog izlaganja } \\
\text { vremenskim utjecajima }\end{array}$} & \multicolumn{3}{|c|}{$\begin{array}{c}\text { After } 250 \text { h artificial } \\
\text { weathering } \\
\text { Nakon } 250 \text { h umjetnog } \\
\text { izlaganja vremenskim } \\
\text { utjecajima }\end{array}$} & \multicolumn{3}{|c|}{$\begin{array}{c}\text { After } 500 \text { h artificial } \\
\text { weathering } \\
\text { Nakon } 500 \text { h umjetnog } \\
\text { izlaganja vremenskim } \\
\text { utjecajima }\end{array}$} \\
\hline & $R a$ & $R z$ & $R q$ & $R a$ & $R z$ & $R q$ & $R a$ & $R z$ & $R q$ \\
\hline Control / kontrolni uzorci & 3.75 & 19.90 & 4.73 & 4.78 & 28.59 & 6.39 & 4.74 & 26.39 & 5.89 \\
\hline $\begin{array}{l}\text { ATFB + Liquid glass } \\
\text { ATFB + tekuće staklo }\end{array}$ & 0.37 & 2.66 & 0.57 & 0.41 & 2.85 & 0.60 & 0.42 & 2.72 & 0.60 \\
\hline $\begin{array}{l}\mathrm{APB}+\text { Liquid glass } \\
A P B+\text { tekuće staklo }\end{array}$ & 0.25 & 1.53 & 0.33 & 0.31 & 1.67 & 0.40 & 0.33 & 1.65 & 0.38 \\
\hline $\begin{array}{l}\text { BA + Liquid glass } \\
B A+\text { tekuće staklo }\end{array}$ & 0.18 & 1.40 & 0.25 & 0.23 & 1.54 & 0.32 & 0.24 & 1.57 & 0.32 \\
\hline \multirow[t]{3}{*}{$\begin{array}{l}\text { Liquid glass } \\
\text { tekuće staklo }\end{array}$} & 0.31 & 2.53 & 0.46 & 0.42 & 2.74 & 0.70 & 0.52 & 2.83 & 0.64 \\
\hline & \multicolumn{5}{|c|}{$\begin{array}{c}\text { Change after } 250 \text { hours, \% } \\
\text { Promjena nakon } 250 \mathrm{~h}, \%\end{array}$} & \multicolumn{4}{|c|}{$\begin{array}{c}\text { Change after } \mathbf{5 0 0} \text { hours, \% } \\
\text { Promjena nakon } 500 \mathrm{~h}, \%\end{array}$} \\
\hline & $R a$ & & $R z$ & $R q$ & & $R a$ & $R z$ & & $R q$ \\
\hline Control / kontrolni uzorci & 27.73 & & 43.71 & 35.30 & & 26.66 & 32.66 & & 24.73 \\
\hline $\begin{array}{l}\text { ATFB + Liquid glass } \\
\text { ATFB + tekuće staklo }\end{array}$ & 12.53 & & 7.18 & 6.06 & & 16.00 & 2.61 & & 6.06 \\
\hline $\begin{array}{l}\mathrm{APB}+\text { Liquid glass } \\
A P B+\text { tekuće staklo }\end{array}$ & 24.77 & & 9.24 & 22.77 & & 32.57 & 7.86 & & 17.21 \\
\hline $\begin{array}{l}\text { BA + Liquid glass } \\
B A+\text { tekuće staklo }\end{array}$ & 33.33 & & 10.32 & 28.00 & & 38.88 & 12.56 & & 29.86 \\
\hline $\begin{array}{l}\text { Liquid glass } \\
\text { tekuće staklo }\end{array}$ & 38.70 & & 8.69 & 54.34 & & 70.96 & 12.25 & & 41.30 \\
\hline
\end{tabular}


weathering, the untreated (control) specimen had average values of $R a, R z$, and $R q$ of $3.75,19.90$, and 4.73 respectively. Results showed that the surface roughness values of the untreated (control) group were higher than those of the other treatment groups before and after weathering. Light irradiation degrades mainly the middle lamella, which is located between cell walls to hold the cells together. This degradation increases the roughness of the wood material surface (Tolvaj et al., 2014). The increase in wood roughness is also related to sudden changes in moisture (absorption and desorption of water) causing the presence of superficial cracks in addition to the leaching of lignin degraded by natural weathering (Kerber et al., 2016). In addition to biotic factors, abiotic factors, such as sunlight, rain, wind, and sandblast, can also affect the surface of wood (Salla et al., 2012).

The results obtained in this research are therefore consistent with the literature references, and show that the smoothest surface was obtained for APB-impregnated and LG-coated Scots pine.

\section{CONCLUSIONS}

\section{ZAKLJUČAK}

This research was carried out to improve the weathering performance of Scots pine wood. Different impregnation and finishing combinations resulted in diverse weathering patterns affecting Scots pine wood surface hardness, color changes, and surface roughness. There was a noticeable decrease in surface hardness after the weathering of the non-treated Scots pine samples. However, there was a significant increase in surface hardness after the weathering of impregnated and coated samples. Artificial weathering caused a decrease of Scots pine wood lightness $\left(\Delta L^{*}\right)$, with the highest decrease observed in the untreated (control) samples. The best color stabilization after weathering was noticed in APB-impregnated and LG-coated Scots pine. Total color changes were lowest for borates-impregnated and LG-coated Scots pine when compared with only LG-coated wood. All treatment scenarios resulted in positive (less advanced) changes of $\Delta a^{*}$ and $\Delta b^{*}$ after weathering. The artificial weathering process caused an increase in surface roughness of control (untreated) and all other treatment groups. Borates-impregnated and LG-coated Scots pine had smoother surfaces than the control wood.

Borates-impregnated and LG-coated Scots pine hardened its surface after weathering. Moreover, such finishing resulted in smoother surfaces than those of the untreated (control) wood. Borates impregnation before LG coating assures better color stability than just coating with liquid glass.

\section{REFERENCES}

\section{LITERATURA}

1. Baysal, E., 2008: Some physical properties of varnish coated wood preimpregnated with copper-chromated boron (CCB) after 3 months of weathering exposure in southern eagen sea region. Wood Research, 53: 43-54.
2. Baysal, E., 2011: Surface hardness of oriental beech preimpregnated with CCB before varnish coating after accelerated lightfastness and accelerated aging. Wood Research, 56: 489-498.

3. Baysal, E., 2012: Surface characteristics of CCA treated Scots pine after accelerated weathering. Wood Research, 57: 375-382.

4. Baysal, E.; Tomak, E. D.; Ozbey, M.; Altin, E., 2014: Surface properties of impregnated and varnished Scots pine wood after accelerated weathering. Coloration Technology, 130: 140-146.

https://doi.org/10.1111/cote.12070.

5. Berdahl, P.; Akbari, H.; Levinson, R.; Miller, W. A., 2008: Weathering of roofing materials - an overview. Construction and Building Materials, 22: 423-433. https://doi.org/10.1016/j.conbuildmat.2006.10.015.

6. Cakicier, N.; Korkut, S.; Korkut, D. S.; Kurtoglu, A.; Sonmez, A., 2011: Effects of QUV accelerated aging on surface hardness, surface roughness, glossiness and color difference for some wood species. International Journal of Physical Sciences, 6: 1929-1939.

7. Cristea, M. V.; Riedl, B.; Blanchet, P., 2010: Enhancing the performance of exterior waterborne coatings for wood by inorganic nanosized UV absorbers. Progress in Organic Coatings, 69: 432-441. https://doi.org/10.1016/j.porgcoat.2010.08.006.

8. David, N.; Hon, S.; Shiraishi, N., 2000: Wood and cellulosic chemistry. $2^{\text {nd }}$ ed. Marcel Dekker, New York. https://doi.org/10.1021/ja015237p.

9. De Meijer, M., 2002: Comparison between laboratory water permeability tests and wood moisture content of full-scale window frames. Surface Coatings International Part B: Coatings Transactions, 85: 131-137.

10. Dundar, A.; Acy, H.; Yildiz, A., 2008: Yield performance and nutritional contents of three oyster mushroom species cultivated on wheat stalk. African Journal of Biotechnology, 7: 3497-3501.

11. Evans, P.; Chowdhury, M. J., Mathews, B.; Schmalzl, K.; Ayer, S.; Kiguchi, M.; Kataoka, Y., 2005: Weathering and surface protection of wood. Handbook of Environmental Degradation of Materials. William Andrew Publishing. Norwich.

12. Fell, D., 2002: Consumer visual evaluation of Canadian wood species. Project no. 3282.

13. Ghosh, S. C.; Militz, H.; Mai, C., 2009: Natural weathering of Scots pine (Pinus sylvestris L.) boards modified with functionalised commercial silicone emulsions. BioResources, 4: 659-673.

14. Herrera, R.; Sandak, J.; Robles, E.; Krystofiak, T.; Labidi, J., 2018: Weathering resistance of thermally modified wood finished with coatings of diverse formulations. Progress in Organic Coatings, 119: 145-154. https://doi.org/10.1016/j.porgcoat.2018.02.015.

15. Hiziroglu, S., Graham, M., 1998: Effect of press closing time and target thickness on surface roughness of particleboard. Forest Products Journal, 48: 50-54.

16. Hon, D. N. S., Chang, S. T., 1985: Photoprotection of wood surfaces by wood-ion complexes. Wood and Fiber Science, 17: 92-100.

17. Huang, X.; Kocaefe, D.; Kocaefe, Y.; Boluk, Y.; Pichette, A., 2012: A spectrocolorimetric and chemical study on color modification of thermally modified wood during artificial weathering. Applied Surface Science, 258: 53605369. https://doi.org/10.1016/j.apsusc.2012.02.005.

18. Jankowska, A., Kozakiewicz, P., 2014: Comparison of outdoor and artificial weathering using compressive properties. Wood Research, 59: 245-252.

19. Karagoz, M.; Aksu, S.; Gozuacık, C.; Kara, K., 2011: Microphthalma europaea egger (Diptera: Tachinidae). a 
new record for Turkey. Turk J Zool. Tübitak. 35: 887889. https://doi.org/10.3906/zoo-0911-112.

20. Kartal, S. N.; Green, F. I., 2002: Development and application of colorimetric microassay for determining boron-containing compounds. Forest Products Journal, 52: 75-79.

21. Kartal, S. N.; Imamura, Y., 2004: Effects of N'-N-(1,8naphthalyl) hydroxylamine (NHA-Na) and hydroxynaphthalimide (NHA-H) on boron leachability and biological degradation of wood. Holz als Roh und Werkstoff, 62: 378-385.

22. Kerber, P. R.; Stangerlin, D. M.; Pariz, E.; Melo, R. R.; Souza, A. P.; Calegari, L., 2016: Colorimetry and surface roughness of three amazonian woods submitted to natural weathering. Nativa, 4: 303-307. https://doi.org/10.14583/2318-7670.v04n05a06.

23. Mohebby, B.; Saei, A. M., 2015: Effects of geographical directions and climatological parameters on natural weathering of fir wood. Construction and Building Materials, 94: 684-690.

24. Pandey, K. K., Pitman, A. J., 2002: Weathering characteristics of modified rubberwood (Hevea brasiliensis). Journal of Applied Polymer Science, 85: 622-631. https://doi.org/10.1002/app.10667.

25. Pandey, K. K., 2005: Study of the effect of photo-irradiation on the surface chemistry of wood. Polymer Degradation and Stability, 90: 9-20. https://doi.org/10.1016/j.polymdegradstab.2005.02.009.

26. Petric, M.; Kricej, B.; Humar, M.; Pavlič, M.; Tomazic, M., 2004: Patination of cherry wood and spruce wood with ethanolamine and surface finishes. Surface Coatings International Part B: Coatings Transactions, 87: 195-201. https://doi.org/10.1007/BF02699635.

27. Salem, Mohamed Z. M.; Zidan, Yassin E.; El Hadidi, Nesrin M. N.; Mansour, Maisa M. A.; Abo Elgat, Wael A. A., 2016: Evaluation of usage three natural extracts applied to three commercial wood species against five common molds. International Biodeterioration \& Biodegradation, 110: 206-226. https://doi.org/10.1016/j.ibiod.2016.03.028.

28. Salla, J.; Pandey, K. K.; Srinivas, K., 2012: Improvement of UV resistance of wood surfaces by using $\mathrm{ZnO}$ nanoparticles. Polymer Degradation and Stability, 97: 592-596. https://doi.org/10.1016/j.polymdegradstab.2012.01.013.

29. Sandak, J.; Sandak, A.; Riggio, M., 2015: Characterization and monitoring of surface weathering on exposed timber structures with a multi-sensor approach. International Journal of Architectural Heritage, 9: 674-688. https://doi.org/10.1080/15583058.2015.1041190.

30. Simsek, H., Baysal, E., 2012: An investigation on colour and gloss changes of wood impregnated with borates. Wood Research, 57: 271-277.

31. Sonmez, A.; Budakci, M.; Demirci, Z.; Akkus, M., 2011: The effect of moisture content of the wood on layer performance of water borne varnishes. BioResources, 6: 3166-3177. https://doi.org/10.15376/biores.6.3.3166-3177.

32. Temiz, A.; Yildiz, U. C., Aydin, I.; Eikenes, M.; Alfredsen, G.; Colakoglu, G., 2005: Surface roughness and color characteristics of wood treated with preservatives after accelerated weathering test. Applied Surface Science, 250: $35-42$

33. Tolvaj, L.; Molnar, Z.; Magoss, E., 2014: Measurement of photodegradation-caused roughness of wood using a new optical method. Journal of Photochemistry and Photobiology B: Biology, 134: 23-26. https://doi.org/10.1016/j.jphotobiol.2014.03.020.

34. Tomak, E. D.; Ustaomer, D.; Yildiz, S.; Pesman, E., 2014: Changes in surface and mechanical properties of heat treated wood during natural weathering. Measurement, 53: 30-39.

https://doi.org/10.1016/j.measurement.2014.03.018.

35. Turkoglu, T.; Baysal, E.; Kureli, I.; Toker, H.; Ergun, M. E., 2015: The effects of natural weathering on hardness and gloss of impregnated and varnished scots pine and oriental beech wood. Wood Research, 60: 833-844.

36. Thevenon, M. F.; Pizzi, A.; Haluk, J.P., 1997: Non toxic albumin and soja borates as ground-contact wood preservatives. Holz als Roh und Werkstoff, 55: 293-296

37. Ustun, S.; Baysal, E.; Turkoglu, T.; Toker, H.; Sacli, C.; Peker, H., 2016: Surface characteristics of Scots pine treated with chemicals containing some copper compounds after weathering. Wood Research, 61: 903-914.

38. Woodard, A. C., Milner, https://www.sciencedirect.com/ science/article/pii/B978008100370100007X\#! H. R., 2016: Sustainability of construction materials. Woodhead Publishing Series in Civil and Structural Engineering. https://doi.org/10.1016/C2014-0-02849-3.

39. Yalinkilic, M. K.; Ilhan, R.; Imamura, Y.; Takahashi, M.; Demirci, Z.; Yalinkilic, A. C., 1999: Weathering durability of CCB-impregnated wood for clear varnish coatings. Journal of Wood Science, 45: 502-514. https://doi.org/10.1007/BF00538961.

40. Yildiz, S.; Yildiz, U. C.; Tomak, E. D., 2011: The effects of natural weathering on the properties of heat-treated alder wood. BioResources, 6: 2504-2521. 10.15376/biores.6.3.2504-2521.

41. Zhang, X., 2003: Photo-resistance of alkylammonium compound treated wood. M. Sc. Thesis. University of British Columbia, Canada.

42. Zhong, Z. W.; Hiziroglu, S.; Chan, C. T. M., 2013: Measurement of the surface roughness of wood based materials used in furniture manufacture. Measurement, 46: 1482-1487. https://doi.org/10.1016/j.measurement.2012.11.041.

43. ***ASTM D1536-58, 1964: Tentative method of test color difference using the color master differential colorimeter.

44. ***ASTM D358-98, 1998: Standard specification for wood to be used as panels in weathering tests of coatings.

45. ***ASTM D1413-07e1, 2007: Standard test method for wood preservatives by laboratory soil block cultures.

46. ***ASTM D3023-98, 2013: Standard practice for determination of resistance of factory-applied coatings on wood products to stains and reagents.

47. ***ASTM D4366-14, 2014: Standard test methods for hardness of organic coatings by pendulum damping tests.

48. ***ASTM G154-06, 2016: Standard practice for operating fluorescent light apparatus for UV exposure of nonmetallic materials.

49. ***DIN 4768, 1990: Determination of values of surface roughness parameters $R a, R z, R \max$ using electrical contact (stylus) instruments, concepts and measuring conditions.

50. ***http://www.isonem.com/ (Accessed Feb. 3, 2019).

\section{Corresponding address:}

\section{MUSTAFA KUCUKTUVEK}

Antalya Bilim University

Faculty of Fine Arts and Architecture

Department of Interior Architecture and Environmental Design

Antalya, TURKEY

e-mail: mustafa.kucuktuvek@antalya.edu.tr 